\title{
A digital approach to protein identification and quantity estimation using tandem nanopores, peptidases, and database search
}

\author{
G. Sampath
}

\begin{abstract}
A digital approach to protein identification and quantity estimation using electrical measurements and database search is proposed. It is based on an electrolytic cell with two (three) nanopores and one (two) peptidase(s) covalently attached to the trans side of a pore. An unknown protein is digested by a reagent or peptidase into peptides ending in a known amino acid; the peptides enter the cell, pass through the first pore, and are fragmented by a high-specificity endopeptidase. The second enzyme, if present, is an exopeptidase that cleaves the fragments into single residues after the second pore. Level transitions in an ionic blockade or transverse current pulse due to residues in a fragment or individual pulses due to single residues are counted. This yields the positions of the endopeptidase's target in the peptide, and, together with the peptide's terminal residue, a partial sequence. Search through the Uniprot database for such sequences identifies over $90 \%$ of the proteins in the human proteome. The percentage can be increased by repeating the procedure with other reagents and cells specific to other residues, close to $100 \%$ may be possible. Sample purification to homogeneity is not required as the method applies to an arbitrary mixture of proteins; the quantity of a protein in the sample can be estimated from the number of identifying peptides sensed over a long run. A Fokker-Planck model gives minimum enzyme turnover intervals required for ordered sensing of peptide fragments. With thick $(80-100 \mathrm{~nm})$ pores, required pulse resolution times are within the capability of CMOS detectors. The method can be implemented with existing technology; several related issues are discussed.
\end{abstract}

Keywords: protein identification; peptide sequencing; protein quantification; electrolytic cell; nanopore; human proteome

\section{Introduction}

Currently sequencing and identification of proteins are largely based on the established techniques of Edman degradation, ${ }^{1,2}$ gel electrophoresis, ${ }^{1,2}$ and mass spectrometry. ${ }^{3}$ Sequencing tends to use bulky or expensive devices and/or time-consuming procedures; this has led to efforts aimed at developing portable/hand-held low-cost fast-turnaround devices. $^{4,5}$ In particular, nanopores have been investigated for their potential use in the analysis and study of DNA ${ }^{6}$ and proteins/peptides. ${ }^{7-10}$ Recently a tandem electrolytic cell with cleaving enzymes was proposed for sequencing of DNA ${ }^{11}$ or peptides. ${ }^{12}$ It has two single cells in tandem, with the structure [cis1, upstream pore (UNP), trans1/cis2, downstream pore (DNP), trans2]. An enzyme covalently attached to the downstream side of UNP successively cleaves the leading monomer in a polymer threading through UNP; the monomer translocates through DNP where the ionic current blockade it causes is used (along with other discriminators ${ }^{12}$ ) to identify it. With DNA the enzyme is an exonuclease, ${ }^{11}$ with peptides it is an amino or carboxy peptidase. ${ }^{12}$ The process is label-free and does not require immobilization of the analyte.

Here a low-cost alternative for protein identification is proposed in which a partial sequence is obtained for a peptide and used to identify the protein by comparison with sequences in a target proteome. Partial sequencing is done with a tandem cell ${ }^{11,12}$ and an endopeptidase (Method 1), or a double tandem cell, endopeptidase, and exopeptidase (Method 2). The first enzyme breaks the peptide into fragments, the second breaks fragments into residues. The fragments/residues translocate through a pore and cause ionic current blockades or modulate a transverse current across the pore; ${ }^{6}$ the pore/transverse current pulses or level transitions within are counted. With an endopeptidase specific to an amino acid a list of integers corresponding to the positions of the amino acid in the peptide sequence is produced. Along with the peptide's terminating residue this yields a partial sequence, which is compared with sequences in a protein database such as Uniprot. Calculations show that with this approach at least $93 \%$ of the proteins in the human proteome can be identified. Purification of the assay sample to homogeneity is not required as the method applies equally to a mixture of proteins, with the quantity of a protein in a mixture being estimated from the number of its identifying peptides. The proposed approach may be extended to include modified amino acids.

This is a digital technique based on pulse counting, it differs from other nanopore sequencing and identification techniques based on analog measurements of pulse magnitude or width (equivalently analyte residence time in a nanopore) of a pore ionic or transverse current. ${ }^{6,11,12}$ The approach is similar in some ways to a recent theoretical proposal ${ }^{13}$ for peptide identification that combines fluorescent labeling with a series of Edman degradation cycles to identify the N-terminal residues of an immobilized peptide, followed by database search. In contrast, the proposal presented here does not use analyte immobilization, labeling, or repeated wash cycles.

\section{Protein identification and quantity estimation: method and materials}

An unknown protein $P$ is identified in five stages:

1. Fragment $\mathrm{P}$ into peptides ending in amino acid $\mathrm{X}_{0}$.

2. Break peptide into fragments ending in amino acid $\mathrm{X}_{1} \neq \mathrm{X}_{0}$ (Methods 1 and 2). Break a fragment into individual residues (Method 2).

3. Find number of residues in each fragment obtained from Stage 2 . 
4. Assemble partial sequence of peptide; mark unknown residues with wild card *.

5. Match partial sequence with sequences in proteome of interest and identify P, hopefully uniquely.

Stage 1. A highly specific chemical or peptidase targets a single amino acid $\mathrm{X}_{0}$. Examples include cyanogen bromide, which cleaves after methionine (M), and GluC protease, which cleaves after glutamic acid (E). (For a list of selected reagents/peptidases see Table A-4 in the Appendix, which has been adapted from an online review ${ }^{14}$ that includes a list of comprehensive references.) This results in the protein being broken into peptides that end in $\mathrm{X}_{0}$.

Stage 2. The positions of occurrence of a single residue $\mathrm{X}_{1}$ in a peptide are obtained by targeting it with a highly specific peptidase in a tandem cell. Peptidases with high specificity include GluC (which targets E), ArgC proteinase (arginine, R), AspN endopeptidase (aspartic acid, D), and LysC lysyl endopeptidase (lysine, K). See Table A-4 in the Appendix. In turn a peptide fragment can be cleaved into a series of individual residues by an exopeptidase capable of cleaving a wide range of residue types at the carboxyl or amino end. Examples include Carboxypeptidase I (CPD-Y), Carboxypeptidase II (CPD-MII), and Leucine Aminopeptidase (LAP). ${ }^{15-17}$

Stage 3. A tandem cell is used to count level transitions in a pore ionic current or transverse current pulse that is modulated by a fragment translocating through a nanopore, or individual such pulses due to single residues cleaved from the fragment. Two methods are considered.
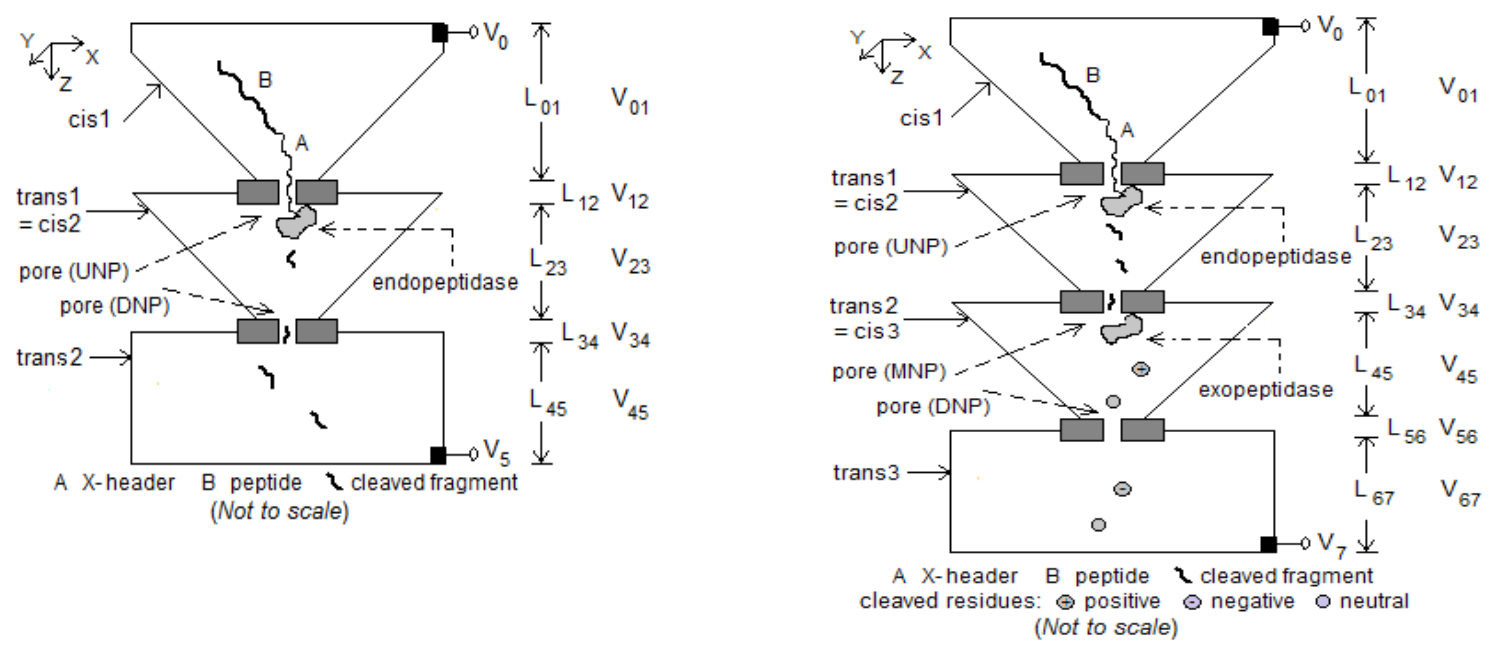

Figure 1 (left). Tandem cell for peptide sequencing. Dimensions: 1) cis 1 : box of height $1 \mu \mathrm{m}$ tapering to $100 \mathrm{~nm}^{2}$;2) membrane with UNP: length $10-20 \mathrm{~nm}$, diameter $10 \mathrm{~nm}$; 3) trans $1 /$ cis 2 : box of height $1 \mu \mathrm{m}$ tapering from $1 \mu \mathrm{m}^{2}$ to $10 \mathrm{~nm}^{2}$; 4) membrane with DNP: length 10-20 nm, diameter $3 \mathrm{~nm} ; 5)$ trans 2 : box of height $1 \mu \mathrm{m}$, side $1 \mu \mathrm{m}$. Endopeptidase covalently attached to downstream side of UNP. Electrodes at top of cis 1 and bottom of trans 2 . $\mathrm{V}_{05}=\sim 115 \mathrm{mV}$.

Figure 2 (right). Double tandem cell for peptide sequencing. Dimensions: 1) cis 1: box of height $1 \mu \mathrm{m}$ tapering to $\left.100 \mathrm{~nm}^{2} ; 2\right) \mathrm{membrane}$ with UNP: length 10-20 nm, diameter $10 \mathrm{~nm}$; 3) trans $1 /$ cis2: box of height $1 \mu \mathrm{m}$ tapering from $1 \mu \mathrm{m}^{2}$ to $10 \mathrm{~nm}^{2}$; 4) membrane with MNP (middle nanopore): length $10-20 \mathrm{~nm}$, diameter $3 \mathrm{~nm}$; 5) trans $2 /$ cis 3 : box height $1 \mu \mathrm{m}$ tapering from $1 \mu \mathrm{m}^{2}$ to $\left.10 \mathrm{~nm}^{2} ; 6\right) \mathrm{membrane}$ with DNP: length 40-50 nm, diameter $3 \mathrm{~nm}$; 7) trans3: box of height $1 \mu \mathrm{m}$, cross-section $1 \mu \mathrm{m}^{2}$. Endopeptidase (exopeptidase) covalently attached to downstream side of UNP (MNP). Electrodes at top of cis 1 and bottom of trans $3 . \mathrm{V}_{07}=\sim 180 \mathrm{mV}$.

In Method 1 the structure in Figure 1 is used. A peptide with a poly-X header ( $\mathrm{X}=$ one of the charged amino acids: Arg, Lys, Glu, Asp; the charge on $\mathrm{X}$ depends on the $\mathrm{pH}$ value) is drawn into UNP by the electric field due to $\mathrm{V}_{05}(=\sim 110 \mathrm{mV})$, most of which ( $\sim 98 \%)$ drops across the two pores. ${ }^{6}$ An endopeptidase specific to amino acid $X_{1}$ attached downstream of UNP cleaves the peptide after (or before) all $n(\geq 0)$ points where $X_{1}$ occurs. The resulting $n+1$ fragments (the first of which ends in $\mathrm{X}_{0}$ ) translocate to and through DNP, where level crossings in the resulting pore ionic current blockade or a transverse current across DNP are used to count the residues in a fragment.

In Method 2 the double tandem cell in Figure 2 is used. A peptide is cleaved into fragments by an endopeptidase as in Method 1. An exopeptidase (amino or carboxy) covalently attached downstream of the middle nanopore (MNP) cleaves successive residues in a fragment, the residues translocate through DNP and blockade the pore ionic current or modulate the transverse current. The resulting single pulses are counted.

In both methods a tandem cell specific to amino acid $\mathrm{X}_{1}$ produces an ordered list of integers equal to the lengths of successive fragments in which the last residue is the target $\mathrm{X}_{1}$ (except the first fragment, which ends in $\mathrm{X}_{0}$ ). If the cell generates a single integer, the target is not in the peptide.

Stage 4. A partial sequence $S_{x}{ }^{\prime}$ for peptide $P_{x}$ is partially assembled as follows:

- Step 1: Replace fragment lengths from cell with cumulative lengths (= target positions of $\mathrm{X}_{1}$ in the peptide). 
- Step 2: Invert position-identity pairs to obtain $\mathrm{S}_{\mathrm{x}}$ (with $\mathrm{X}_{0}$ in the last position).

- Step 3: Insert wild card * in all unknown positions in $\mathrm{S}_{\mathrm{X}}$.

The resulting sequence is a partial sequence containing $\mathrm{X}_{1}$ and ending in $\mathrm{X}_{0}$.

Stage 5. Standard string matching algorithms can be used to search for $S_{X}$ among sequences in a protein database such as Uniprot ${ }^{18}$ or PDB. More general matching algorithms ${ }^{19}$ may be used for error detection and correction.

Cell output. The output for a given $\mathrm{X}_{0}-\mathrm{X}_{1}$ pair is a series of partial sequences containing $\mathrm{X}_{1}$ and ending in $\mathrm{X}_{0}$ corresponding to peptides from the unknown protein entering the cell in some random order. If the assay sample consists of a mixture of proteins, the output corresponds to peptides from any of the proteins in the mixture in any order. As discussed below, by repeating the procedure with different $\mathrm{X}_{0}$ and $\mathrm{X}_{1}$, different partial sequences can be obtained for the same protein and used to increase the identification rate.

\subsection{Database search and results}

A partial sequence obtained in the procedure described above can be used to identify the container protein based on precomputing all identifying peptides for each protein in a given proteome. Identification is then a matter of matching the partial sequence output by a cell with a precomputed sequence. The process is illustrated with the human proteome (Uniprot database id UP000005640, manually reviewed subset with 20207 sequences) for the following set of cleavage targets: $\mathrm{X}_{0}=$ $\mathrm{M}$ (first stage), and $\mathrm{X}_{1}=\mathrm{R}$ (second stage).

\section{Precomputation}

1. All subsequences of proteins in the protein that end in $M$ are extracted, they correspond to the peptides generated by the action of cyanogen bromide (see above). Every one of these peptides has exactly one $\mathrm{M}$ which is also the last residue in the peptide.

2. Enter wild card * into every position in every peptide sequence in the database where $\mathrm{R}$ and $\mathrm{M}$ do not occur.

3. Each subsequence (peptide) is compared with every other reduced subsequence from Step 2. If there is no match mark the peptide as a unique identifier.

The resulting data are available for download; see Appendix.

\section{Identification}

1. Read output data from Stage 4 above, this corresponds to a partial sequence for a peptide.

2. Compare partial sequence with sequences of identifiable proteins in precomputed database; output identity of (unique) container protein if there is a match.

The percentage of proteins with at least one identifying subsequence (created by cyanogen bromide in Stage 1 and cleaved after each occurring $\mathrm{R}$ by $\mathrm{ArgC}$ in Stage 2) is found to be $90.49 \%$. It may be increased by using other combinations of cleaving chemical/enzyme and peptidases (Table A-4, Appendix). Figure 3 shows the distribution of the number of proteins vs the number of identifying peptides in a protein for two sets of cleavage choices in Stages 1 and 2. The total coverage is the union of the sets of proteins with at least one unique identifier obtained from all $\mathrm{X}_{0}-\mathrm{X}_{1}$ pairs used.

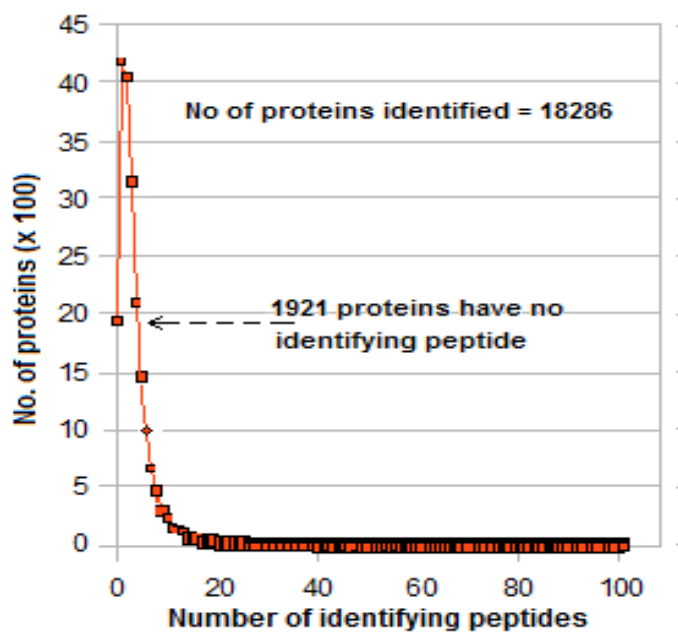

(a)

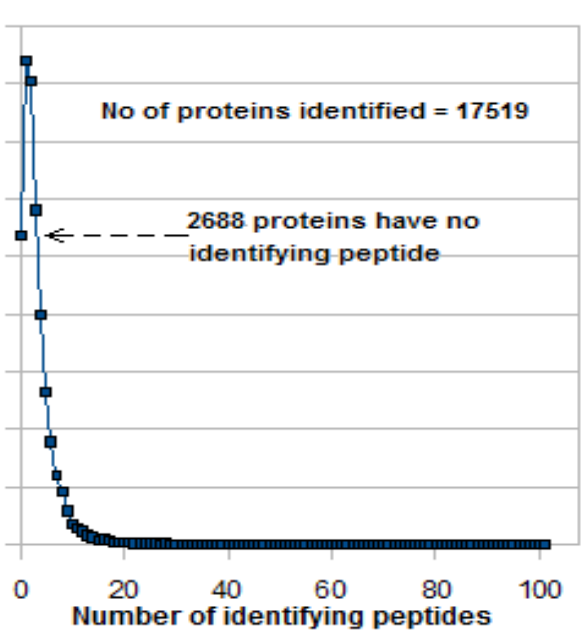

(b)

Figure 3. Number of proteins with a given number of identifying peptides in the human proteome (UP000005640, manually reviewed subset with 20207 sequences): (a) cleave M in Stage 1 and R in Stage 2; (b) cleave Y in Stage 1 and R in Stage 2

Table 1 shows the increase when sequencing is done twice by targeting $\mathrm{M}$ or $\mathrm{Y}$ in Stage 1, with $\mathrm{R}$ targeted both times in 
Stage 2 .

Table 1: Increase in number of identifiable proteins from multiple runs with different cleavage targets (Total number of proteins in human proteome UP000005640 $\mathbf{2 0 2 0 7}$ )

\begin{tabular}{|c|c|c|c|c|c|c}
\hline $\begin{array}{c}\text { Run } \\
\text { no. }\end{array}$ & $\begin{array}{c}\text { Target in } \\
\text { Stage 1 }\end{array}$ & $\begin{array}{c}\text { No of peptides created in } \\
\text { Stage 1 }\end{array}$ & $\begin{array}{c}\text { Target in } \\
\text { Stage 2 }\end{array}$ & $\begin{array}{c}\text { No. of proteins } \\
\text { identified / not identified }\end{array}$ & $\begin{array}{c}\text { Not identified in this run, } \\
\text { identified in the other }\end{array}$ & $\begin{array}{c}\text { Total proteins identified in } \\
\text { both runs / not identified }\end{array}$ \\
\hline 1 & M & 261048 & $\mathrm{R}$ & $\begin{array}{c}18286=90.49 \% \\
1921=9.51 \%\end{array}$ & 522 & $18808=93.07 \%$ \\
& & 321376 & $\mathrm{R}$ & $17519=86.69 \%$ & 1288 & $1399=6.93 \%$ \\
& & $\mathrm{Y}$ & $2688=13.30 \%$ & & \\
\hline
\end{tabular}

\subsection{Estimating the quantity of a protein in a mixture}

Consider an assay of a mixture of proteins given by $\left\{\left(\mathrm{N}_{\mathrm{i}}, \mathrm{P}_{\mathrm{i}}, \mathrm{I}_{\mathrm{i}}\right): \mathrm{i}=1,2, \ldots\right\}$ where $\mathrm{N}_{\mathrm{i}}$ is the number of molecules of the ith protein in the mixture, $\mathrm{P}_{\mathrm{i}}$ the number of peptides per molecule of the protein (this is equal to the number of peptides created in Stage 1 from a single molecule), and $\mathrm{I}_{\mathrm{i}}\left(0 \leq \mathrm{I}_{\mathrm{i}} \leq \mathrm{P}_{\mathrm{i}}\right)$ the number of identifying peptides per molecule. For a given chemical agent/peptidase in Stage 1 the $\mathrm{P}_{\mathrm{i}} \mathrm{s}$ are known, and for the set of peptidases used in the cells in Stage 2 the $\mathrm{I}_{i} \mathrm{~S}$ are known by computation. $\mathrm{N}_{\mathrm{i}}$ is the desired unknown. For example, with $\mathrm{M}$ targeted in Stage 1 and $\mathrm{R}$ in Stage 2, for the protein P31946 in the human proteome $P_{i}=9$ and $I_{i}=1$. Peptides generated in Stage 1 from the mixture enter a cell in some random order and are partially sequenced and used to identify their container proteins. Let the total number of peptides processed in

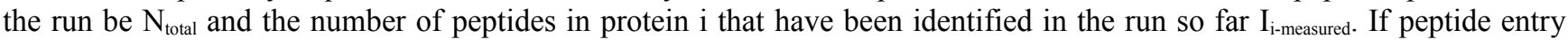
into a cell is totally random, then after a sufficiently long run $\mathrm{N}_{\mathrm{i}}$ can be estimated as

$$
\tilde{\mathrm{N}}_{\mathrm{i}}=\mathrm{I}_{\mathrm{i} \text {-measured }} / \mathrm{I}_{\mathrm{i}}
$$

The corresponding fraction is

$$
\hat{\mathrm{G}}_{\mathrm{i}}=\tilde{\mathrm{N}}_{\mathrm{i}} / \mathrm{N}_{\text {total }}
$$

The number of peptides that do not yield identifying information is

$$
\mathrm{N}_{\text {non-identifying }}=\mathrm{N}_{\text {total }}-\sum \mathrm{I}_{\mathrm{i} \text {-measured }}
$$

where the summation is over all the identified proteins. This number includes peptides that are found in more than one protein and may also include impurities in the assay sample. If the sample is contaminated there seems to be no easy way to separate the two so unidentified sample proteins that are not impurities remain unestimated (even though the percentage is likely small).

\section{Necessary conditions for ordered recognition of fragments from a peptide}

Nanopore-based sequencing relies on the ability to measure changes in current flow when an analyte molecule is present. This current may be an ionic current from cis to trans, a transverse electronic current across the pore membrane, or a transverse tunneling current across a gap in the membrane. ${ }^{6}$ The measurement ability is closely related to the bandwidth of the detector, see discussion in Section 4 below.

Since the charge carried by a peptide is highly variable and may be negative, 0 , or positive, the two methods described above rely on diffusion as the primary mechanism for translocation of a fragment or residue, modified by the drift field. They are studied through the properties of the basic tandem cell, which has been modeled with a Fokker-Planck equation. ${ }^{11,12}$ Central to the model is the solution of a boundary value problem in which the trans side of a pore is viewed as a reflecting boundary for a cleaved fragment or residue, so the net diffusion tends to be in the cis-to-trans direction (with $\mathrm{V}_{05}, \mathrm{~V}_{07}>$ 0 ). The main quantities of interest are the mean $\mathrm{E}(\mathrm{T})$ and variance $\sigma^{2}(\mathrm{~T})$ of the time $\mathrm{T}$ taken by a particle to translocate through a trans compartment or pore of length $\mathrm{L}$ (in the latter case it is $\approx$ the width of the pore ionic blockade or transverse current pulse) and with applied potential difference of V. Expressions for $E(T)$ and variance $\sigma^{2}(T)$ are given in Section A-1 of the Appendix, detailed derivations may be found elsewhere. ${ }^{11,12}$

For fragments to yield position information for residues targeted by the endopeptidase, they must be sensed in their natural order in the second pore in Method 1 (or residues from fragments in the third pore in Method 2). The following is a set of necessary conditions for this to happen.

Necessary conditions

C1: a) At most one cleaved fragment may occupy DNP (Method 1) or MNP (Method 2) at any time;

b) At most one cleaved residue may occupy DNP (Method 2).

C2: a) Cleaved fragments (Method 1) or residues (Method 2) must arrive at DNP in sequence order; 
b) Cleaved fragments must arrive at MNP in sequence order (Method 2).

C3: a) A residue translocating through DNP must have a blockade pulse width $>\mathrm{T}_{\text {detector }}\left(\right.$ Method 2); here $\mathrm{T}_{\text {detector }}=$ time resolution of the detector circuit $\left(=\sim 1 \mu\right.$ s with CMOS circuits $\left.^{20}\right)$.

b) A fragment with $\mathrm{L}_{\mathrm{f}}$ residues must have a blockade pulse width in DNP $>\mathrm{L}_{\mathrm{f}} \mathrm{T}_{\text {detector }}(\operatorname{Method} 1)$.

The following are some factors to consider in ensuring that these conditions are satisfied.

- The pore ionic blockade or transverse current pulse width, which is effectively the fragment or residue's residence time in DNP. It is approximated by the mean translocation time through DNP in both methods.

- The charge carried by a peptide fragment (and hence its mobility $\mu$ ). As it depends on the constituent amino acids it has a wide range of values, which directly affects the translocation time (see Section A-2 in the Appendix for the relevant equations). Thus fragments with high negative charge have very high speeds of translocation which may result in misses ('deletes'), while those with high positive charge are 'lost' to diffusion because they are too slow. Figure A-1 in the Appendix shows the frequency distribution of all $20^{7}$ peptides of length $\mathrm{L}_{\mathrm{F}}=7$ as a function of $\mu$ or $\mu / \mathrm{D}$ at $\mathrm{pH}=7$ (physiological $\mathrm{pH}$ ), where $\mathrm{D}$ is the diffusion constant of the fragment. (Note the multimodal shape and slight negative skew.) These distributions are used in the Appendix to estimate the percentage of misses (deletes) and losses.

Satisfying the necessary conditions

- $\quad C 1$ and $C 2$ can be satisfied by requiring the enzymes to cleave at a given minimum rate. Enzyme reactions being stochastic processes, reaction rates are random variables with a distribution of values. The minimum rates required are estimated using standard statistical methods.

- $\quad C 3$ can be satisfied through the use of a sufficiently thick pore. Thus the pore ionic blockade or transverse modulated current pulse width is proportional to the square of pore length (Equations A-1 through A-4), so a thicker pore can significantly increase translocation times and thus lower the required bandwidth (or equivalently increase the resolution time needed to sense the pulse). This is contrary to the usual practice of using thinner pores to achieve better discrimination, ${ }^{6}$ but is appropriate here because residues do not have to be identified, they only have to be counted. (A side benefit of this is that thick synthetic pores are usually easier to fabricate than thin ones. ${ }^{21}$ ) See Discussion in Section 4.

With suitable values for the pore length, applied voltage, and peptide length all three conditions can be satisfied with $\mathrm{T}_{\text {detector }}$ $=\sim 1 \mu \mathrm{s}$. See Appendix for details.

\section{Comparing the two methods}

Method 1 has a more compact physical structure and uses only one enzyme, but the need to recognize transitions in a blockade pulse due to a fragment reduces the maximum length that can be determined accurately. The ionic current is also lower. Method 2 can use a shorter (that is, thinner) DNP and a higher potential difference (leading to a higher ionic current). (This is not as serious a problem with transverse currents, which are on the order of $\mathrm{nA},{ }^{21}$ compared with at most $100 \mathrm{~s}$ of $\mathrm{pA}$ with ionic currents. ${ }^{6}$ ) However, as noted earlier, the reaction time required of the endopeptidase is larger because of the need to sense more than one residue in DNP; also both the endopeptidase and the exopeptidase need to cleave at a sufficiently low rate and in synchrony. Notice that in Method 2 even if the exopeptidase is inefficient and does not cleave after every single residue, the number of residues would be counted correctly if DNP senses transitions between residues in a pulse due to a fragment with more than one residue.

\section{Discussion}

Implementation of the proposed scheme appears both feasible and practical given that the required chemistry, nanopore fabrication technology, detector electronics (with needed bandwidth), and database search methods are all currently available. Some related issues are considered next.

1) Counting pulses or transitions in a pulse. On the face of it counting transitions in a pulse due to residues in a fragment would appear to be easier with the following methods: a) using single-atom thick graphene ${ }^{22}$ or molybdenum disulphide $\left(\mathrm{MoS}_{2}\right)$ sheets, ${ }^{23}$ both of which make counting of transitions easier; b) detecting level crossings in a transverse electronic or tunneling current pulse across graphene or silicon gaps ${ }^{24,25}$ and c) using a narrow biological nanopore like MspA, which has a constriction in its short $s^{26}{ }^{26}$ that may aid in recognizing the transitions. However all of these methods would require bandwidths in the tens of $\mathrm{MHz}$ if directly used in the approach described here. To bring the bandwidth down to 1-2 $\mathrm{MHz}$ (corresponding to a pulse width resolution of $\sim 1 \mu \mathrm{s}$ ), thick pores may be considered, as discussed in Section 3. With silicon compounds like $\mathrm{Si}_{3} \mathrm{~N}_{4}$ thick pores $(50-100 \mathrm{~nm})$ are actually easier to manufacture than thin ones. ${ }^{21,27}$ With graphene, hourglass-shaped pores may be fabricated from graphite (which is a stack of graphene layers ${ }^{28}$ ), but stability may be an issue because of graphite's flakiness. Biological pores like AHL or MspA may also be stacked, for example a stack of 10 AHL pores can provide a pore about $60-80 \mathrm{~nm}$ thick.

2) Location of peptidases. The cleaving action of an enzyme (endopeptidase or exopeptidase) requires it to be in the path of the peptide or fragment emerging from the respective pore (UNP or MNP) on the trans side. This can be ensured by covalently attaching the enzyme to the trans side of the pore membrane. Such covalent attachment has been discussed for DNA sequencing using two different approaches: exosequencing of mononucleotides ${ }^{29}$ and sequencing by synthesis using 
heavy tags attached to the bases..$^{30}$ In both approaches an exonuclease or polymerase is attached to the cis side of the pore membrane. This could result in significant errors due to cleaved bases or tags being lost to diffusion in the cis chamber (deletions) or entering the pore out of order (delete-and-insert). ${ }^{31}$ In the present approach the peptidases are located on the trans side so deletions cannot occur. Out-of-order arrivals at the sensing pore (fragments at DNP in Method 1; fragments at MNP and residues at DNP in Method 2) are precluded as long as the necessary conditions given in Section 3 are satisfied.

3) Solution $\mathrm{pH}$. Solution $\mathrm{pH}$ plays an important role for two reasons: a) the charge carried by a fragment, which is highly variable and not known in advance, is a function of $\mathrm{pH}$ (compare with DNA, where all nucleotide types have approximately the same electron charge of -q with a small variability due to $\mathrm{pH}$ ); b) its effect on enzyme reaction rates. The choice of $\mathrm{pH}$ is a tradeoff between enzyme efficiency and being able to control translocation speeds; this may be determined by experiment. 4) Fabrication. A recent review of nanopore sequencing includes notes on fabrication techniques. ${ }^{27}$ Tandem-pore-like structures have been fabricated and used in polymer studies recently. One of these has been used to trap and analyze DNA, ${ }^{32}$ with the trans $1 /$ cis 2 chamber functioning like a test-tube. A similar structure has been used to measure the mobility of DNA molecules ${ }^{33}$ In contrast with conventional nanopore sequencing methods, where the aim is to fabricate thin $(\sim 1 \mathrm{~nm})$ pores that are usually synthetic (for example $\mathrm{Si}_{3} \mathrm{~N}_{4}$ ), as noted earlier the thick $(80-100 \mathrm{~nm}$ ) pores required in the proposed scheme may be more easily fabricated.

6) Other. See Appendix.

Successful implementation of the proposed method could lead to a portable easy-to-use low-cost fast-turnaround digital device for protein identification and quantity estimation. Neither analyte labeling nor immobilization is required, only electrical measurements are used, and bandwidths required are within limits. The sample need not be purified to homogeneity; the quantity of a protein in a non-homogeneous mixture can be estimated from the measured number of its identifying peptides. Tandem cells of the required size and shape can be fabricated with available technology, enzymes of the required specificity are available, and sequence data are easily assembled from digital signals output by multiple cells. The assembled partial sequence can be rapidly compared with sequences in a proteome database to find a unique match if one exists. Finally, the low data storage and processing requirements of the proposed method suggest easy integration with hand-held diagnostic and mobile electronic devices (similar to a recently introduced genome sequencer with a USB interface ${ }^{4}$.

Supplementary information. Data files with identifying sequences for each protein in the human proteome for two sets of cleaving options are available.

\section{References}

[1] McKee and McKee. Biochemistry, $5^{\text {th }}$ edn., New York, Oxford University Press, 2011.

[2] J. M. Berg, J. L. Tymoczko, and L. Stryer. Biochemistry, th $^{\text {th }}$ edn., New York, W H Freeman, 2012.

[3] H. Steen and M. Mann. "The ABC'S (and XYZ's) of peptide sequencing." Nature Reviews, 2004, 5, 699-711.

[4] J. Quick, A. Quinlan, and N. Loman. "A reference bacterial genome dataset generated on the MinION portable single-molecule nanopore sequencer.” Gigascience, 2014, 3, 22-27.

[5] M. Yang, T.-Y. Kim, H.-C. Hwang, S.-K. Yi, D.-H. Kim, “Development of a palm portable mass spectrometer," J. Am. Soc. Mass Spectrom. $2008,19,1442-1448$.

[6] M. Wanunu, "Nanopores: a journey towards DNA sequencing." Phys Life Rev, 2012, 9, 125-158.

[7] W. Timp, A. M. Nice, E. M. Nelson, V. Kurz, K. Mckelvey, and G. Timp. “Think small: nanopores for sensing and synthesis.” IEEE Access, 2014, 2, 1396-1408.

[8] A. Oukhaled, L. Bacri, M. Pastoriza-Gallego, J-M. Betton, and J. Pelta, "Sensing proteins through nanopores: fundamental to applications," ACS Chem. Biol., 2012, 7, 1935-1949.

[9] D. Wu, S. Bi, L. Zhang, and J. Yang. "Single-molecule study of proteins by biological nanopore sensors.” Sensor, 2014, 14, $18211-18222$.

[10] D. Rotem, L. Jayasinghe, M. Salichou, and H. Bayley, "Protein detection by nanopores equipped with aptamers", J. Amer. Chem. Soc., 2012, 134, 2781-2787.

[11] G. Sampath, "A tandem cell for nanopore-based DNA sequencing with exonuclease," RSC Adv., 2015, 5, 167-171.

[12] G. Sampath, "Amino acid discrimination in a nanopore and the feasibility of sequencing peptides with a tandem cell and exopeptidase," RSC $A d v$, , 2015, 5, 30694-30700.

[13] J. Swaminathan, A. A. Boulgakov, E. M. Marcotte, “A theoretical justification for single molecule peptide sequencing," PLoS Comput. Biol., 2015, 11, e1004080.

[14] http://web.expasy.org/peptide cutter/. Accessed July 11, 2015.

[15] K. Breddam, "Serine carboxypeptidases: a review," Carlsberg Res. Commun., 1986, 51, 83-128.

[16] K. Breddam and M. Ottesen, "Determination of c-terminal sequences by digestion with serine carboxypeptidases: the influence of enzyme specificity," Carlsberg Res. Commun., 1987, 52, 55-63.

[17] A. Taylor, “Aminopeptidases: structure and function," FASEB J., 1993, 7, 290-298.

[18] http://www.uniprot.org/uniprot. Accessed July 4, 2015.

[19] D. Gusfield. String Algorithms. Cambridge University Press, Cambridge (UK), 1997.

[20] J. K. Rosenstein, M. Wanunu, C. A. Merchant, M, Drndic, and K. L. Shepard, "Integrated nanopore sensing platform with sub-microsecond temporal resolution," Nature Methods, 2012, 9, 487-492.

[21] A. Balan, B. Machielse, D. Niedzwiecki, J. Lin, P. Ong, R. Engelke, K. L. Shepard, and M. Drndic', "Improving signal-to-noise performance for DNA translocation in solid-state nanopores at MHz bandwidths," Nano Lett., 2014, 14, 7215-7220. 
[22] M. Drndic, "Sequencing with graphene pores," Nat. Nanotech., 2014, 9, 743.

[23] A. B. Farimani, K. Min, N. R. Aluru, "DNA base detection using a single-layer $\mathrm{MoS}_{2}$ ", ACS Nano, 2014, 8, 7914-7922.

[24] M. Tsutsui, M. Taniguchi, K. Yokota, T. Kawai, "Identifying single nucleotides by tunnelling current," Nat. Nano, $2010,5,286-90$.

[25] Y. Zhao, B. Ashcroft, P. Zhang, H. Liu, S. Sen, W. Song, J. Im, B. Gyarfas, S. Manna, S. Biswas, C. Borges, and S. Lindsay, "Singlemolecule spectroscopy of amino acids and peptides by recognition tunneling," Nature Nanotech., 2014, 9, 466-473.

[26] T. Z. Butler, M Pavlenok, I. M. Derrington, M Niederweis, J. H. Gundlach, "Single-molecule DNA detection with an engineered MspA protein nanopore," PNAS, 2008, 105, 20647-20652.

[27] Y. Wang, Q. Yang, Z. Wang, "The evolution of nanopore sequencing," Front. Genet., 2015, 5, 449.

[28] A. van der Zande, "The structure and mechanics of atomically-thin graphene membranes," PhD thesis, 2011, Cornell University.

[29] J. Clarke, H-C. Wu, L Jayasinghe, A. Patel, S. Reid and H. Bayley, "Continuous base identification for single-molecule nanopore DNA sequencing," Nature Nanotech., 2009, 4, 265-270.

[30] S. Kumar, C. Tao, M. Chien, B. Hellner, A. Balijepalli, J. W. F. Robertson, Z. Li, J. J. Russo, J. E. Reiner, J. J. Kasianowicz, and J. Ju, "PEGlabeled nucleotides and nanopore detection for single molecule DNA sequencing by synthesis," Scientific Reports, 2012, DOI:10.1038/srep00684. [31] J. E. Reiner, A. Balijepalli, J. F. Robertson, D. L. Burden, B. S. Drown, and J. J. Kasianowicz, "The effects of diffusion on an exonuclease/nanopore-based DNA sequencing engine," J. Chem Phys., 2012, 137, 214903.

[32] X. Liu, M. M. Skanata, D. Stein, "Entropic cages for trapping DNA near a nanopore," Nat. Comms. 2015, 6, doi:10.1038/ncomms7222.

[33] M. Langecker, D. Pedone, F. C. Simmel, and U. Rant, "Electrophoretic time-of-flight measurements of single DNA molecules with two stacked nanopores," Nano Lett., 2011, 11, 5002-5007.

\section{Appendix}

\section{A-1 Translocation statistics of tandem cell}

Following [11,12], the mean $\mathrm{E}(\mathrm{T})$ and variance $\sigma^{2}(\mathrm{~T})$ of the translocation time $\mathrm{T}$ over a channel of length $\mathrm{L}$ that is reflective at the top and absorptive at the bottom with applied potential difference of $\mathrm{V}$ are given by

$$
E(T)=\left(L^{2} / D \alpha\right)[1-(1 / \alpha)(1-\exp (-\alpha))]
$$

and

$$
\sigma^{2}(T)=\left(\mathrm{L}^{2} / \mathrm{D} \alpha^{2}\right)^{2}(2 \alpha+4 \alpha \exp (-\alpha)-5+4 \exp (-\alpha)+\exp (-2 \alpha))
$$

where

$$
\mathrm{v}_{\mathrm{z}}=\mu \mathrm{V} / \mathrm{L} ; \quad \alpha=\mathrm{v}_{\mathrm{z}} \mathrm{L} / \mathrm{D}=\mu \mathrm{V} / \mathrm{D}
$$

Here $\mathrm{v}_{\mathrm{z}}$ is the drift velocity due to the electrophoretic force experienced by a charged particle in the $\mathrm{z}$ direction, which can be 0 , negative, or positive. For $\mathrm{v}_{\mathrm{z}}=0$, these two statistics are

$$
\mathrm{E}_{0}(\mathrm{~T})=\mathrm{L}^{2} / 2 \mathrm{D} ; \quad \sigma_{0}^{2}(\mathrm{~T})=(1 / 6)\left(\mathrm{L}^{4} / \mathrm{D}^{2}\right)
$$

If each section in the double tandem cell is considered independently these formulas can be applied to all the relevant sections: trans $1 /$ cis 2 $\left(\mathrm{T}=\mathrm{T}_{\text {trans } 1 / \text { cis } 2} ; \mathrm{L}=\mathrm{L}_{23}\right), \mathrm{MNP}\left(\mathrm{T}=\mathrm{T}_{\mathrm{MNP}} ; \mathrm{L}=\mathrm{L}_{34}\right)$, trans $2 /$ cis $3\left(\mathrm{~T}=\mathrm{T}_{\text {trans } 2 / \text { cis } 3} ; \mathrm{L}=\mathrm{L}_{45}\right), \mathrm{DNP}\left(\mathrm{T}=\mathrm{T}_{\mathrm{DNP}} ; \mathrm{L}=\mathrm{L}_{56}\right)$, and trans $3\left(\mathrm{~T}=\mathrm{T}_{\text {trans }} ; \mathrm{L}=\right.$ $\mathrm{L}_{67}$ ). For an analysis of behavior at the interface between two sections see [11,12].

\section{A-2 Dependence of particle translocation on solution $\mathrm{pH}$, charge, diffusion constant, and mobility}

Equations A-1 through A-4 involve a number of physical-chemical properties of amino acids: electrical charge (itself dependent on solution $\mathrm{pH}$ ) [34], hydrodynamic radius, diffusion constant, and mobility. The following paragraphs provide a quantitative description of this dependence and allow calculation of fragment properties as they apply to peptide sequencing in a tandem cell with endopeptidase. In particular this information is used in the next section to derive a required condition for effective sequencing.

Table A-1

\begin{tabular}{|c|c|c|c|c|c|c|c|c|c|}
\hline Peptide end or amino acid & Amino end & Carboxy end & $\mathrm{R}$ & $\mathrm{D}$ & $\mathrm{C}$ & $\mathrm{E}$ & $\mathrm{H}$ & $\mathrm{K}$ & $\mathrm{Y}$ \\
\hline kA value & 2.34 & 9.69 & 12.48 & 3.86 & 8.33 & 4.25 & 6.0 & 10.53 & 10.07 \\
\hline
\end{tabular}

1) The electrical charge carried by a peptide (fragment) $P_{x}$ can be calculated with the Henderson-Hasselbach equation. Let the set of amino acids be $\mathbf{A A}=[\mathrm{A}, \mathrm{R}, \mathrm{N}, \mathrm{D}, \mathrm{C}, \mathrm{Q}, \mathrm{E}, \mathrm{G}, \mathrm{H}, \mathrm{I}, \mathrm{L}, \mathrm{K}, \mathrm{M}, \mathrm{F}, \mathrm{P}, \mathrm{S}, \mathrm{T}, \mathrm{W}, \mathrm{Y}, \mathrm{V}]$ where AA[i] is the i-th amino acid, $1 \leq \mathrm{i} \leq 20$. Let the $\mathrm{pH}$ value of the solution (electrolyte) be $\mathrm{p}, \mathrm{kC}=\mathrm{kA}$ value of the carboxy end $=9.69, \mathrm{kN}=\mathrm{kA}$ value of the amino end $=2.34, \mathrm{~N}_{\mathrm{X}}$ the number of times residue $X$ occurs in the peptide $(X=R, H, K), N_{Z}$ the number of times residue $Z$ occurs $(Z=D, C, E, Y)$, and $k X$ and $k Z$ the $k A$ values of $X$ and $Z$ respectively. $k A$ values are given by Table $A-1$. The charge multiplier $C_{P x}$ on the peptide is given by

$$
\mathrm{C}_{\mathrm{Px}}=10^{\mathrm{kC}} /\left(10^{\mathrm{p}}+10^{\mathrm{kC}}\right)-10^{\mathrm{p}} /\left(10^{\mathrm{p}}+10^{\mathrm{kN}}\right)+\sum_{\mathrm{x}} 10^{\mathrm{kX}} /\left(10^{\mathrm{p}}+10^{\mathrm{kX}}\right)-\sum_{\mathrm{z}} 10^{\mathrm{P}} /\left(10^{\mathrm{p}}+10^{\mathrm{kZ}}\right)
$$

where the summations are over the $N_{X}$ and $N_{Z}$ occurrences of $X$ and $Z$ respectively in $P_{x}$.

2) The hydrodynamic radius $R_{P x}$ of peptide $P_{x}=X_{1} X_{2} \ldots X_{N}$ is obtained recursively as follows: 


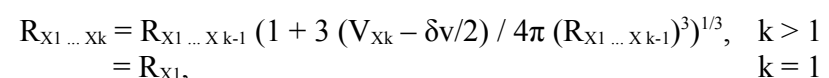

where $\mathrm{V}_{\mathrm{Xk}}$ and and $\delta \mathrm{v}$ are the van der Waals volumes of $\mathrm{X}_{\mathrm{k}}$ and a single molecule of water. Hydrodynamic radii of individual amino acids are given in [35] and van der Waals volumes in [36] (both sets of values are reproduced in the Supplement to [12]). This formula holds for small peptides (up to $\sim 20$ residues).

3) The diffusion constant and mobility of $P_{x}$ are given by

$$
\mathrm{D}_{\mathrm{Px}}=\mathrm{k}_{\mathrm{B}} \mathrm{T}_{\mathrm{R}} / 6 \pi \eta \mathrm{R}_{\mathrm{Px}} \quad \mu_{\mathrm{Px}}=\mathrm{C}_{\mathrm{Px}} \mathrm{q} / 6 \pi \eta \mathrm{R}_{\mathrm{Px}}
$$

Here $\mathrm{k}_{\mathrm{B}}$ is the Boltzmann constant $\left(1.3806 \times 10^{-23} \mathrm{~J} / \mathrm{K}\right), \mathrm{T}_{\mathrm{R}}$ is the room temperature $\left(298^{\circ} \mathrm{K}\right), \eta$ is the solvent viscosity $(0.001$ Pa.s $)$, $\mathrm{q}$ is the electron charge $\left(1.619 \times 10^{-19}\right.$ coulomb), and $\mathrm{C}_{\mathrm{Px}}$ is a multiplier.

Figure 1 shows the distribution of the number of peptides of length 7 vs mobility $\mu$ and $\mu / \mathrm{D}$ (= $\alpha$ with V set to 1$)$ over all $20^{7}$ of them.
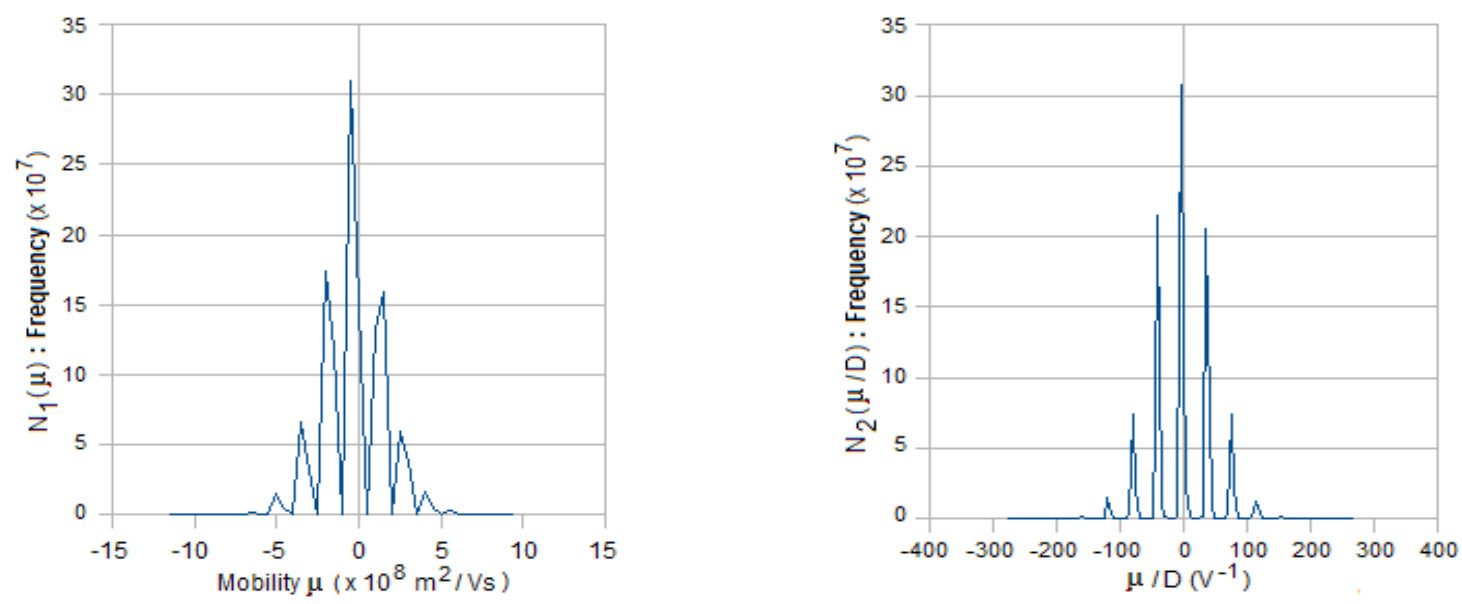

Figure A-1. Distribution of number of peptides of length 7 vs mobility $\mu$ and the ratio of mobility to diffusion coefficient ( $\mu / \mathrm{D})$.

\section{A-3 Calculating the percentage of misses (deletes) due to fast fragments and losses due to slow fragments}

For fragments that carry a high negative or positive charge the mean translocation time in Equations A-1 and A-4 can be approximated by

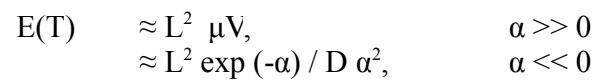

These formulas can be used to estimate the percentage of misses due to fast translocating fragments and slowly moving fragments through DNP in Method 1.

To estimate the former, for a given pore length $\mathrm{L}$, voltage $\mathrm{V}$ across the pore, and blockade pulse width approximated by $\mathrm{E}(\mathrm{T}), \mu$ is written as

$$
\mu=\mathrm{E}(\mathrm{T}) / \mathrm{L}^{2} \mathrm{~V}
$$

The percentage of misses is given by

$$
\% \text { misses }=100\left(1 / 20^{7}\right) \int_{-\infty}^{\mu} N_{1}(\mu) d \mu
$$

The integral in Equation A-10 is the cumulative frequency for $\mathrm{N}_{1}(\mu)$ corresponding to the $\mu$ calculated from Equation A-9. The results are shown in Table A-2 for $\mathrm{V}=100 \mathrm{mV}, \mathrm{L}=100,150,200$, and $250 \mathrm{~nm}$, and two pulse widths: $\mathrm{E}(\mathrm{T})=7 \mu$ s and $10 \mu \mathrm{s}$.

To estimate the percentage of losses rewrite Equation A-8b as

$$
\mathrm{E}(\mathrm{T})=\mathrm{L}^{2} \exp (-\mu \mathrm{V} / \mathrm{D}) / \mathrm{D}(-\mu \mathrm{V} / \mathrm{D})^{2}
$$

This is an implicit function of two parameters, $\mu / \mathrm{D}$ and $\mathrm{D}$. To solve for $\mu / \mathrm{D}$ for a given $\mathrm{E}(\mathrm{T}), \mathrm{L}$, and $\mathrm{V}$, it is approximated by

$$
\mathrm{E}(\mathrm{T}) \approx \mathrm{L}^{2} \exp (-\mu \mathrm{V} / \mathrm{D}) / \mathrm{D}_{\text {avg }}(-\mu \mathrm{V} / \mathrm{D})^{2}
$$


where $\mathrm{D}_{\text {avg }}$ is the average diffusion coefficient of all $20^{7}$ peptides of length 7 . This is a nonlinear equation in $\mu / \mathrm{D}$; the desired root on the real line can be found using standard methods. For a given value of $\mathrm{V}$, the percentage of losses is given by

$$
\% \text { loss }=100\left(1 / 20^{7}\right) \int_{\mu / D}^{\infty} N_{2}(\mu / D) d(\mu / D)
$$

The results are shown in Table A-2 for $\mathrm{V}=100 \mathrm{mV}$ and $\mathrm{L}=100,150,200$, and $250 \mathrm{~nm}$, and $\mathrm{E}(\mathrm{T})=1 \mathrm{~s}$.

Table A-2

\begin{tabular}{|c|c|c|c|c|c|c|c|c|c|}
\hline \multirow[b]{2}{*}{$\mathrm{L}(\mathrm{nm})$} & \multicolumn{3}{|c|}{ Pulse width $=7 \mu \mathrm{s}$} & \multicolumn{3}{|c|}{ Pulse width $=10 \mu \mathrm{s}$} & \multicolumn{3}{|c|}{ Pulse width $=1 \mathrm{~s}$} \\
\hline & $\begin{array}{c}\mu \\
\left(\mathrm{m}^{2} / \mathrm{Vs}\right)\end{array}$ & $\mathrm{N}_{1}(\mu)$ & $\begin{array}{c}\text { Percentage } \\
\text { deletions }\end{array}$ & $\begin{array}{c}\mu \\
\left(\mathrm{m}^{2} / \mathrm{Vs}\right)\end{array}$ & $\mathrm{N}_{1}(\mu)$ & $\begin{array}{c}\text { Percentage } \\
\text { deletions }\end{array}$ & $\begin{array}{l}\mu / \mathrm{D} \\
\left(\mathrm{V}^{-1}\right)\end{array}$ & $\mathrm{N}_{2}(\mu / \mathrm{D})$ & $\begin{array}{l}\text { Percentage } \\
\text { losses }\end{array}$ \\
\hline 100 & -1.43 & $4.1 \times 10^{8}$ & 32.09 & -1 & $7.2 \times 10^{8}$ & 56.27 & $1.6 \times 10^{2}$ & $2.06 \times 10^{5}$ & 0.02 \\
\hline 150 & -3.22 & $1.19 \times 10^{8}$ & 9.3 & -2.25 & $2.93 \times 10^{8}$ & 22.89 & $1.52 \times 10^{2}$ & $2.52 \times 10^{8}$ & 0.19 \\
\hline 200 & -5.72 & $2.97 \times 10^{6}$ & 0.23 & -4 & $2.2 \times 10^{7}$ & 1.72 & $1.45 \times 10^{2}$ & $2.52 \times 10^{8}$ & 0.19 \\
\hline 250 & -8.94 & $7.4 \times 10^{3}$ & 0 & -6.25 & $2.5 \times 10^{6}$ & 0.2 & $1.4 \times 10^{2}$ & $2.52 \times 10^{8}$ & 0.19 \\
\hline
\end{tabular}

Figures A-2 and A-3 show similar distributions for peptide lengths 12 and 16.
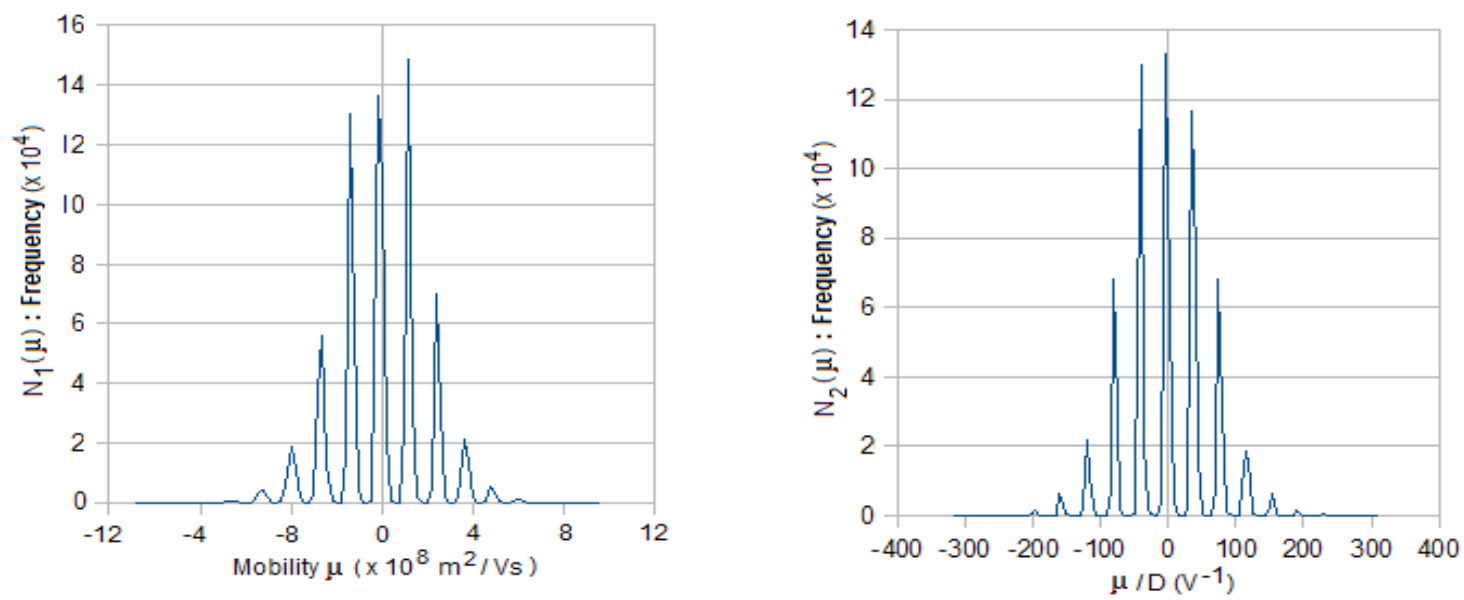

Figure A-2. Distribution of number of peptides vs mobility $\mu$ and the ratio of mobility to diffusion coefficient $(\mu / \mathrm{D})$. Numbers based on $10^{6}$ randomly generated peptide strings of length 12 .
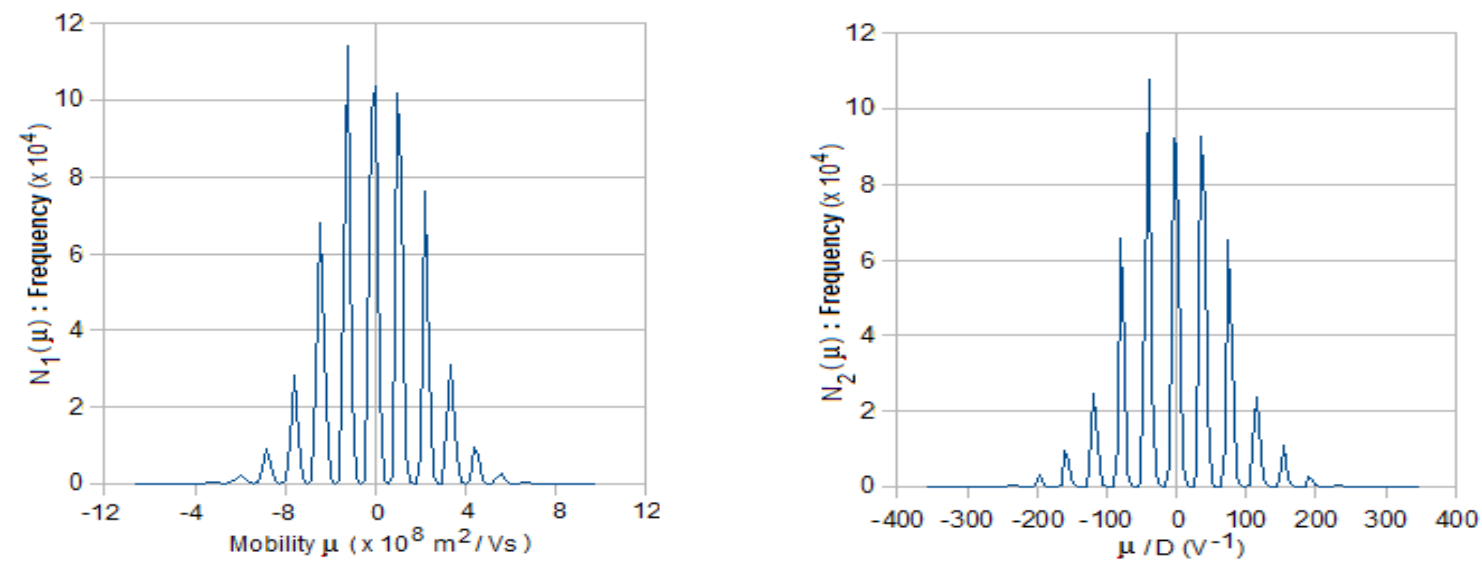

Figure A-3. Distribution of number of peptides vs mobility $\mu$ and the ratio of mobility to diffusion coefficient ( $\mu / \mathrm{D})$. Numbers based on $10^{6}$ randomly generated peptide strings of length 16.

\section{A-4 Translocation statistics of single residues}


bioRxiv preprint doi: https://doi.org/10.1101/024158; this version posted September $8,2015$. The copyright holder for this preprint (which was not certified by peer review) is the author/funder, who has granted bioRxiv a license to display the preprint in perpetuity. It is made available under aCC-BY-NC-ND 4.0 International license.

The mean and standard deviation of the time taken by a single residue through trans $2 /$ cis 3 and DNP (Method 2) are shown in Table A-3 as a function of $\mathrm{pH}$.

Table A-3

Method 2: Translocation time of single residues through trans $2 /$ cis $3\left(10^{-3} \mathrm{~s}\right)$ and DNP $\left(10^{-6} \mathrm{~s}\right)$

\begin{tabular}{|c|c|c|c|c|c|c|c|c|c|c|c|c|}
\hline \multirow{3}{*}{$\underset{\text { acid }}{\text { Amino }}$} & \multicolumn{4}{|c|}{$\mathrm{pH}=3$} & \multicolumn{4}{|c|}{$\mathrm{pH}=7$} & \multicolumn{4}{|c|}{$\mathrm{pH}=11$} \\
\hline & \multicolumn{2}{|c|}{$\operatorname{trans} 2 / \operatorname{cis} 3$} & \multicolumn{2}{|c|}{ DNP } & \multicolumn{2}{|c|}{$\operatorname{trans} 2 / \mathrm{cis} 3$} & \multicolumn{2}{|c|}{ DNP } & \multicolumn{2}{|c|}{$\operatorname{trans} 2 / \operatorname{cis} 3$} & \multicolumn{2}{|c|}{ DNP } \\
\hline & Mean & Std dev & Mean & Std dev & Mean & Std dev & Mean & Std dev & Mean & Std dev & Mean & Std dev \\
\hline A & 0.1528 & 0.1248 & 5.5557 & 4.8187 & 0.1523 & 0.1244 & 3.8857 & 3.1704 & 0.1501 & 0.1222 & 1.2137 & 0.6792 \\
\hline $\mathrm{R}$ & 0.2100 & 0.1721 & 156.44 & 155.54 & 0.2094 & 0.1715 & 79.93 & 78.98 & 0.2062 & 0.1677 & 5.4214 & 4.4501 \\
\hline $\mathrm{N}$ & 0.1711 & 0.1398 & 6.2241 & 5.3984 & 0.1707 & 0.1394 & 4.3532 & 3.5518 & 0.1682 & 0.1369 & 1.3597 & 0.7609 \\
\hline $\mathrm{D}$ & 0.1731 & 0.1414 & 4.9358 & 4.1143 & 0.1703 & 0.1386 & 1.3264 & 0.7297 & 0.1678 & 0.1362 & 0.7536 & 0.3153 \\
\hline $\mathrm{C}$ & 0.1643 & 0.1342 & 5.9734 & 5.1809 & 0.1637 & 0.1336 & 3.8589 & 3.0969 & 0.1589 & 0.1290 & 0.7143 & 0.2990 \\
\hline Q & 0.1855 & 0.1516 & 6.7462 & 5.8513 & 0.1850 & 0.1510 & 4.7184 & 3.8497 & 0.1823 & 0.1484 & 1.4738 & 0.8248 \\
\hline E & 0.1802 & 0.1472 & 5.8700 & 5.0063 & 0.1771 & 0.1441 & 1.3803 & 0.7596 & 0.1745 & 0.1416 & 0.7835 & 0.3278 \\
\hline G & 0.1332 & 0.1089 & 4.8456 & 4.2028 & 0.1329 & 0.1085 & 3.3891 & 2.7651 & 0.1309 & 0.1066 & 1.0586 & 0.5924 \\
\hline $\mathrm{H}$ & 0.2036 & 0.1668 & 151.08 & 150.21 & 0.2002 & 0.1635 & 6.0541 & 5.0998 & 0.1969 & 0.1603 & 1.5924 & 0.8912 \\
\hline I & 0.1861 & 0.1520 & 6.7671 & 5.8694 & 0.1856 & 0.1515 & 4.7330 & 3.8617 & 0.1828 & 0.1488 & 1.4783 & 0.8273 \\
\hline $\mathrm{L}$ & 0.1947 & 0.1591 & 7.0804 & 6.1411 & 0.1942 & 0.1585 & 4.9521 & 4.0404 & 0.1913 & 0.1557 & 1.5468 & 0.8656 \\
\hline K & 0.2153 & 0.1764 & 160.35 & 159.42 & 0.2147 & 0.1758 & 81.84 & 80.87 & 0.2090 & 0.1703 & 2.1084 & 1.2987 \\
\hline M & 0.1769 & 0.1445 & 6.4329 & 5.5795 & 0.1764 & 0.1440 & 4.4993 & 3.6710 & 0.1738 & 0.1415 & 1.4053 & 0.7865 \\
\hline $\mathrm{F}$ & 0.1924 & 0.1572 & 6.9969 & 6.0686 & 0.1919 & 0.1567 & 4.8937 & 3.9928 & 0.1890 & 0.1539 & 1.5285 & 0.8554 \\
\hline $\mathrm{P}$ & 0.1539 & 0.1257 & 5.5975 & 4.8549 & 0.1535 & 0.1253 & 3.9150 & 3.1942 & 0.1512 & 0.1231 & 1.2228 & 0.6843 \\
\hline $\mathrm{S}$ & 0.1585 & 0.1295 & 5.7646 & 4.9998 & 0.1581 & 0.1291 & 4.0318 & 3.2896 & 0.1557 & 0.1268 & 1.2593 & 0.7048 \\
\hline $\mathrm{T}$ & 0.1746 & 0.1426 & 6.3494 & 5.5071 & 0.1741 & 0.1422 & 4.4409 & 3.6233 & 0.1716 & 0.1397 & 1.3871 & 0.7763 \\
\hline W & 0.2010 & 0.1642 & 7.3102 & 6.3404 & 0.2005 & 0.1637 & 5.1128 & 4.1715 & 0.1975 & 0.1608 & 1.5970 & 0.8937 \\
\hline Y & 0.2050 & 0.1675 & 7.4564 & 6.4672 & 0.2045 & 0.1669 & 5.2070 & 4.2471 & 0.1987 & 0.1613 & 0.9359 & 0.4014 \\
\hline V & 0.1907 & 0.1558 & 6.9342 & 6.0143 & 0.1901 & 0.1553 & 4.8499 & 3.9570 & 0.1874 & 0.1525 & 1.5148 & 0.8477 \\
\hline
\end{tabular}

trans2/cis3: $\quad$ height $=0.5 \mu \mathrm{m} \quad$ radius $=\overline{0.5} \mu \mathrm{m} \quad \overline{\mathrm{V}_{23}=1.2 \mathrm{mV}}$

DNP: $\quad$ height $=80 \mathrm{~nm}$ radius $=2 \mathrm{~nm} \quad \mathrm{~V}_{34}=140 \mathrm{mV}$

\section{A-5 Derivation of necessary conditions for effective sequencing}

It is now shown that the necessary conditions applicable to each of the two methods are satisfied by a large majority ( $\sim 80 \%$ in most cases) of peptide sequences of a given length for a set of typical parameter values. In the following translocation time distributions are assumed to have $6 \sigma$ support $\left(\sigma=\right.$ standard deviation). The following parameter values are assumed: $\mathrm{V}_{05}=\sim 115 \mathrm{mV}(\operatorname{Method} 1) ; \mathrm{V}_{07}=\sim 180 \mathrm{mV}$ (Method 2); detector resolution $=1 \mu \mathrm{s}$; pore $(\mathrm{DNP}, \mathrm{MNP})$ conductance $=\sim 1 \mathrm{nS} ; \mathrm{pH}=7.0 ;$ trans $1 /$ cis 2 height $=$ trans $2 /$ cis 3 height $=0.5$ $\mu \mathrm{m}$, UNP length $=$ MNP length $=10 \mathrm{~nm}$. $\mathrm{V}_{05}$ divides as $\mathrm{V}_{01}=\mathrm{V}_{23}=\mathrm{V}_{45} \approx 1.6 \mathrm{mV}, \mathrm{V}_{12} \approx 10 \mathrm{mV}$, and $\mathrm{V}_{34} \approx 100 \mathrm{mV}$. $\mathrm{V}_{07}$ divides as $\mathrm{V}_{01}=\mathrm{V}_{23}$ $=\mathrm{V}_{45}=\mathrm{V}_{67} \approx 1.5 \mathrm{mV}, \mathrm{V}_{12}=\mathrm{V}_{34} \approx 15 \mathrm{mV}$, and $\mathrm{V}_{56}=140 \mathrm{mV}$. Let $\mathrm{T}_{\text {exo-min }}, \mathrm{T}_{\text {endo-min-2, }}$, and $\mathrm{T}_{\text {endo-min-1 }}$ be the minimum reaction time intervals for the exopeptidase in Method 2, the endopeptidase in Method 2, and the endopeptidase in Method 1 respectively.

Method 2. Referring to Section 3 in the main text Conditions $1 a, 1 b, 2 a, 2 b$, and 3 have to be satisfied. From Table A-3, with $\mathrm{pH}=7.0$, DNP height $=80 \mathrm{~nm}$, and $\mathrm{V}_{56}=140 \mathrm{mV}$, the fastest amino acid is Asp (D) with a translocation time of $\sim 1.33 \mu \mathrm{s}>1 \mu \mathrm{s}$. This satisfies Condition 3.

Let $\mathrm{X}_{1}$ and $\mathrm{X}_{2}$ be two residues cleaved in succession by the exopeptidase. Conditions $1 a, 1 b$, and $2 a$ are satisfied if

$$
\mathrm{E}\left(\mathrm{T}_{\text {trans2/cis3-X1 } 1}\right)+3 \sigma_{\text {trans2/cis2-X! }}+\mathrm{E}\left(\mathrm{T}_{\mathrm{DNP}-\mathrm{X} 1}\right)+3 \sigma_{\mathrm{DNP}-\mathrm{X} 1}<\mathrm{T}_{\text {exo-min }}+\max \left(0, \mathrm{E}\left(\mathrm{T}_{\text {trans2/cis3-X2 }}\right)-3 \sigma_{\text {trans2/cis3-X2 }}\right)
$$

From columns 6 and 7 in the same table the second term in the inequality on the right is 0 , leading to

$$
\mathrm{T}_{\text {exo-min }}>\max _{\mathrm{X}}\left\{\mathrm{E}\left(\mathrm{T}_{\text {trans } 1 / \text { cis } 2-\mathrm{X}}\right)+3 \sigma_{\text {trans } 1 / \text { cis } 2-\mathrm{X}}+\mathrm{E}\left(\mathrm{T}_{\mathrm{DNP}-\mathrm{X}}\right)+3 \sigma_{\mathrm{DNP}-\mathrm{X}}\right\}
$$

over all $\mathrm{X}$. The maximum occurs for $\mathrm{X}=\mathrm{K}(\mathrm{Lys})$, with $\mathrm{E}\left(\mathrm{T}_{\text {trans } 2 / \text { cis } 3-\mathrm{X}}\right)=0.21 \times 10^{-3}, \sigma_{\text {trans } 2 / \text { cis } 3-\mathrm{X}}=0.18 \times 10^{-3}, \mathrm{E}\left(\mathrm{T}_{\mathrm{DNP}-\mathrm{X}}\right)=82 \times 10^{-6}$, and $\sigma_{\mathrm{DNP}-\mathrm{X}}=$ $81 \times 10^{-6}$, leading to

$$
\mathrm{T}_{\text {exo-min }} \approx 1 \mathrm{~ms}
$$


More generally the rate can be calculated for each residue type in a similar way. More generally Figure A-4 shows the mean blockade pulse widths due to single residues in DNP for all 20 residue types for three different lengths of DNP, while Figure A-5 shows $\mathrm{T}_{\text {exo-min }}$ Vs residue type for DNP length $=80 \mathrm{~nm}$.

A peptide that has threaded through UNP encounters the endopeptidase in trans $1 /$ cis 2 and is cleaved into fragments. The latter translocate through trans $1 /$ cis 2 and thread through MNP to be cleaved by the exopeptidase on the downstream side. Consider two successive fragments $\mathrm{F}_{1}$ and $\mathrm{F}_{2}$. Let $\mathrm{L}_{\mathrm{F} 1}$ be the length of a fragment $\mathrm{F}_{1}$. The delay due to cleaving of $\mathrm{F}_{1}$ into single residues by the exopeptidase is $\mathrm{L}_{\mathrm{f} 1} \mathrm{~T}_{\text {exo-min-2. }}$. Conditions $1 a$ and $2 b$ will be satisfied if

$$
\mathrm{E}\left(\mathrm{T}_{\text {trans } 1 / \text { cis2-F1 }}\right)+3 \sigma_{\text {trans } 1 / \text { cis2-F1 }}+\mathrm{E}\left(\mathrm{T}_{\mathrm{MNP}-\mathrm{F} 1}\right)+3 \sigma_{\mathrm{MNP}-\mathrm{F} 1}+\sum_{\mathrm{F} 1} \mathrm{~T}_{\text {exo-min-X }}<\mathrm{T}_{\text {endo-min-2 }}+\max \left(0, \mathrm{E}\left(\mathrm{T}_{\text {trans } 1 / \text { cis2-F2 } 2}\right)-3 \sigma_{\text {trans1/cis2-F2 }}\right)
$$

where $\mathrm{T}_{\text {exo-min- } \mathrm{X}}$ is the cleavage time for residue $\mathrm{X}$ and the summation is over all $\mathrm{L}_{\mathrm{Fl}}$ residues in $\mathrm{F}_{1}$. In the second term on the right side of the inequality, $\sigma_{\text {trans } 1 / \text { cis } 2-\mathrm{F} 2} \approx \mathrm{E}\left(\mathrm{T}_{\text {trans } 1 / \text { cis } 2-\mathrm{F} 2}\right)$, so that $\max \left(0, \mathrm{E}\left(\mathrm{T}_{\text {trans } 1 / \text { cis } 2-\mathrm{F} 2}\right)-3 \sigma_{\text {trans } 1 / \text { cis2 } 2 \mathrm{~F} 2}\right)=0$; this leads to

$$
\mathrm{T}_{\text {endo-min-2 }}=\mathrm{E}\left(\mathrm{T}_{\text {trans } 1 / \text { cis2-F1 } 1}\right)+3 \sigma_{\text {trans } 1 / \text { cis } 2-\mathrm{F} 1}+\mathrm{E}\left(\mathrm{T}_{\mathrm{MNP}-\mathrm{F} 1}\right)+3 \sigma_{\mathrm{MNP}-\mathrm{F} 1}+\sum_{\mathrm{F} 1} \mathrm{~T}_{\text {exo-min-X }}
$$

Figure A-6 shows the distribution of $\mathrm{T}_{\text {endo-min-2 }}$ with $10^{6}$ random peptide sequences with residues in a sequence drawn from a uniform distribution for three different fragment lengths.

Method 1. The development is similar to that for Method 2. Thus Conditions 1a, 2a, and 3 have to be satisfied. With two successive fragments $\mathrm{F}_{1}$ and $\mathrm{F}_{2}$ cleaved by the endopeptidase, Conditions $1 a$ and $2 a$ require

$$
\mathrm{E}\left(\mathrm{T}_{\text {trans } 1 / \text { cis2-F1 } 1}\right)+3 \sigma_{\text {trans } 1 / \text { cis2 } 2 \mathrm{~F} 1}+\mathrm{E}\left(\mathrm{T}_{\mathrm{DNP}-\mathrm{F} 1}\right)+3 \sigma_{\mathrm{DNP}-\mathrm{F} 1}<\mathrm{T}_{\text {endo-min-1 }}+\max \left(0, \mathrm{E}\left(\mathrm{T}_{\text {trans } 1 / \text { cis2-F2 } 2}\right)-3 \sigma_{\text {trans } 1 / \text { cis2-F2 }}\right)
$$

As before the second term on the right is 0 because $\sigma_{\text {trans } 1 / c i s 2-\mathrm{F} 2} \approx \mathrm{E}\left(\mathrm{T}_{\text {trans } 1 / \text { cis2-F2 }}\right)$ which leads to

$$
\mathrm{T}_{\text {endo-min-1 }}=\mathrm{E}\left(\mathrm{T}_{\text {trans } 1 / \text { cis } 2-\mathrm{F} 1}\right)+3 \sigma_{\text {trans } 1 / \text { cis } 2-\mathrm{F} 1}+\mathrm{E}\left(\mathrm{T}_{\mathrm{DNP}-\mathrm{F} 1}\right)+3 \sigma_{\mathrm{DNP}-\mathrm{F} 1}
$$

Figure A-7 shows the distribution of fragment pulse widths for three different fragment lengths. Figure A- 8 shows $\mathrm{T}_{\text {endo-min-1 }}$ for $10^{6}$ random samples of length 12 . For the vast majority of sequences $\mathrm{T}_{\text {endo-min-1 }}$ is $<3 \mathrm{~ms}$. The curve is to the left of the corresponding curve in Method 2 (Figure A-6, red) because the endopeptidase reaction times in the latter include the delay due to the cleaving of residues in a fragment by the exopeptidase (although this is not strictly necessary because the pulses are only counted so they can arrive in any order). The distribution of pulse widths $>12 \mu$ s due to fragments of length $=12$ vs the endopeptidase reaction time is shown in Figure A-9. For nearly $80 \%$ of the sequences (with blockade pulses in which $\mathrm{L}_{\mathrm{F}}$ transitions can be counted) $\mathrm{T}_{\text {endo-min- } 1}<1 \mathrm{~ms}$. In comparison the percentage of pulses that may not be counted correctly is relatively small at $\sim 17 \%$. Incidentally the curves in Figures A- 6 are similar in shape and range to reaction rate graphs for the enzyme Exonuclease I [37].
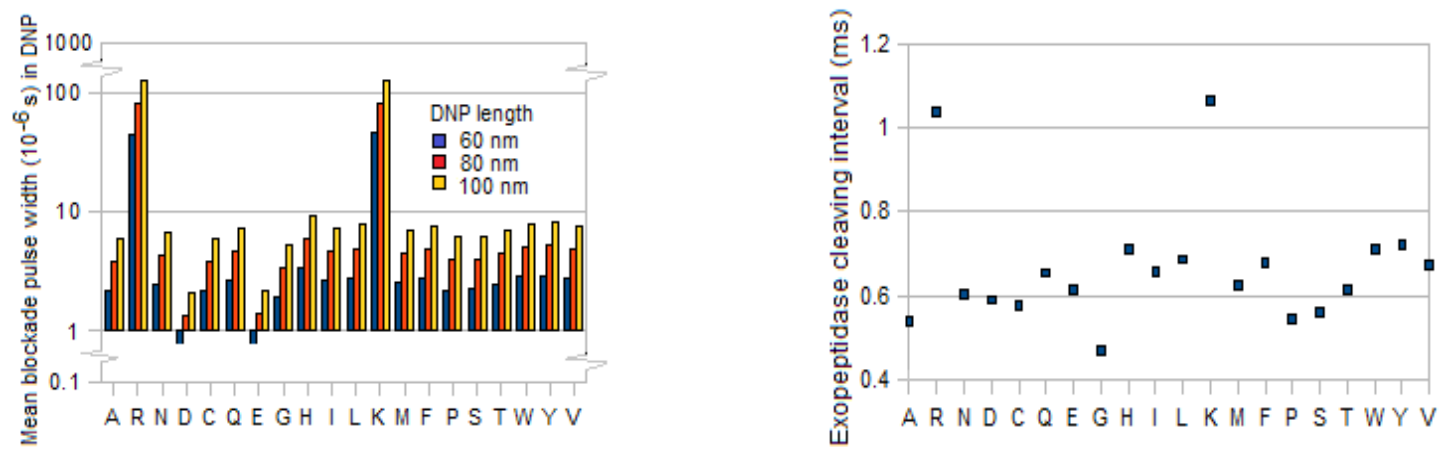

Figure A-4 (left). Mean blockade pulse width ( $\mu \mathrm{s})$ in DNP of different lengths for the 20 individual amino acids in Method 2. trans2 height $=0.5 \mu \mathrm{m}, \mathrm{V}_{56}=140 \mathrm{mV}, \mathrm{V}_{45}=1.2 \mathrm{mV}, \mathrm{pH}=7$.

Figure A-5 (right). Distribution of $\mathrm{T}_{\text {exo-min }}(\mathrm{ms})$ for each amino acid type in Method 2. DNP height $=80 \mathrm{~nm}$, trans 2 height $=0.5 \mu \mathrm{m}, \mathrm{V}_{56}=$ $140 \mathrm{mV}, \mathrm{V}_{45}=1.2 \mathrm{mV}, \mathrm{pH}=7$.

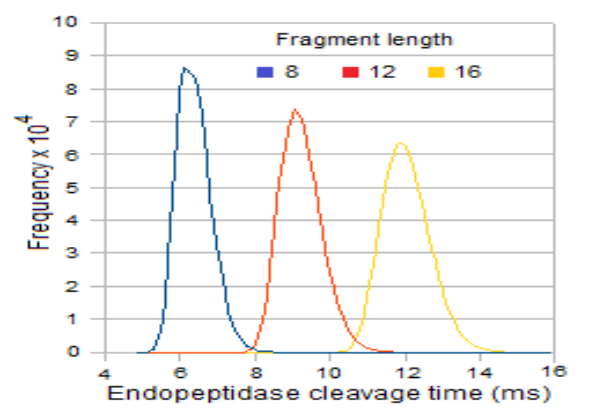

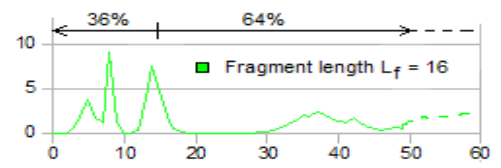
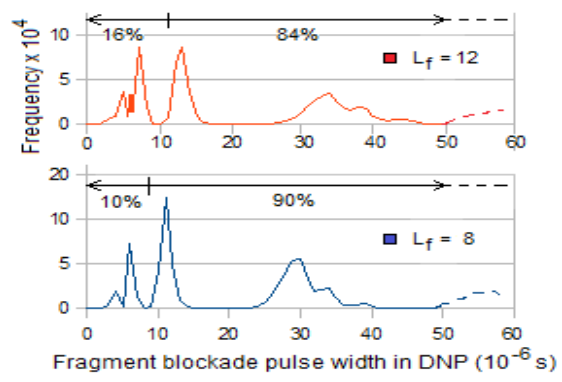
Figure A-6 (left) . Frequency distribution of $\mathrm{T}_{\text {endo-min-2 }}(\mathrm{ms})$ for different fragment lengths $\mathrm{L}_{\mathrm{F}}$ in $\operatorname{Method} 2 . \mathrm{MNP}$ height $=10 \mathrm{~nm}$, trans1 height $=0.5 \mu \mathrm{m}, \mathrm{V}_{23}=1.2 \mathrm{mV}, \mathrm{V}_{34}=20 \mathrm{mV}, \mathrm{pH}=7$.

Figure A-7 (right). Frequency distribution of fragment pulse widths ( $\mu$ s) for different fragment lengths in Method 1 . DNP height $=150$ $\mathrm{nm}$, trans 1 height $=0.5 \mu \mathrm{m}, \mathrm{V}_{34}=100 \mathrm{mV}, \mathrm{V}_{23}=1.2 \mathrm{mV}, \mathrm{pH}=7$.
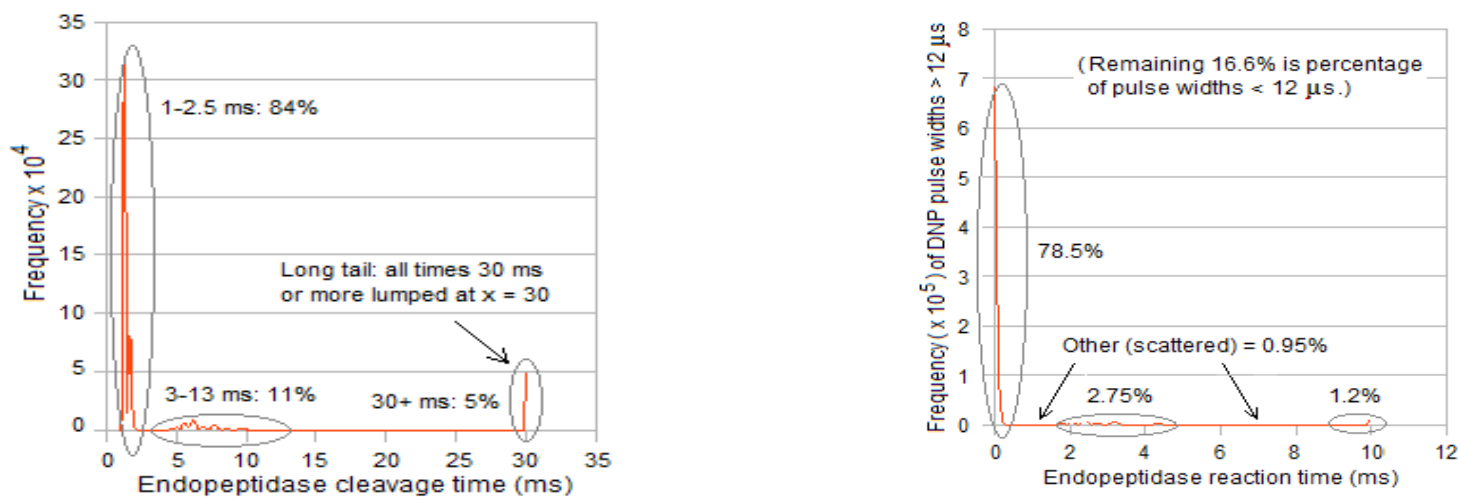

Figure A-8 (left). Frequency distribution of $T_{\text {endo-min-1 }}(\mathrm{ms})$ for fragment length $=12$ in Method 1. DNP height $=150 \mathrm{~nm}$, trans 1 height $=$ $0.5 \mu \mathrm{m}, \mathrm{V}_{34}=100 \mathrm{mV}, \mathrm{V}_{23}=1.2 \mathrm{mV}, \mathrm{pH}=7$.

Figure A-9 (right). Distribution of pulse widths $>12 \mu \mathrm{s}$ for fragment length $=12$ vs $\mathrm{T}_{\text {endo-min-1 }}(\mathrm{ms})$ in Method $1 . \mathrm{DNP}$ height $=150 \mathrm{~nm}$, trans 1 height $=0.5 \mu \mathrm{m}, \mathrm{V}_{34}=100 \mathrm{mV}, \mathrm{V}_{23}=1.2 \mathrm{mV}, \mathrm{pH}=7$.

\section{A-6 Peptidases and chemicals for cleaving and their specificities}

Table A-4 is a summary of selected chemicals and peptidases for use in cleaving of the unknown protein or peptides generated from it at desired locations; it is adapted from [14]. The following notation is used for cleavage sites on a substrate [38]:

$$
\mathrm{N}-\mathrm{P}_{\mathrm{n}}-\ldots-\mathrm{P}_{4}-\mathrm{P}_{3}-\mathrm{P}_{2}-\mathrm{P}_{1}=\mathrm{cut}=\mathrm{P}_{1}{ }^{\prime}-\mathrm{P}_{2}{ }^{\prime}-\mathrm{P}_{3}{ }^{\prime}-\mathrm{P}_{4}{ }^{\prime}-\ldots-\mathrm{P}_{\mathrm{m}}{ }^{\prime}-\mathrm{C}
$$

where - represents a peptide bond, $\mathrm{N}$ is the $\mathrm{N}$-terminal end, and $\mathrm{C}$ is the $\mathrm{C}$-terminal end.

Table A-4

Selected chemical agents for cleaving a protein after or before a specific amino acid (Stage 1)

\begin{tabular}{|c|c|c|c|}
\hline Chemical & Cleavage point and target & Chemical & Cleavage point and target(s) \\
\hline BNPS-Skatole & $\mathrm{N}-\ldots-\mathrm{Trp}=\mathrm{cut}=\ldots-\mathrm{C}$ & Hydroxylamine & $\mathrm{N}-\ldots-\mathrm{Asn}=\mathrm{cut}=\mathrm{Gly}-\ldots-\mathrm{C}$ \\
\hline Cyanogen bromide $(\mathrm{CNBr})$ & $\mathrm{N}-\ldots-\mathrm{Met}=\mathrm{cut}=\ldots-\mathrm{C}$ & Iodosobenzoic acid & $\mathrm{N}-\ldots-\mathrm{Trp}=\mathrm{cut}=\ldots-\mathrm{C}$ \\
\hline Formic acid & $\mathrm{N}-\ldots-\mathrm{Asp}=\mathrm{cut}=\ldots-\mathrm{C}$ & $\mathrm{NTCB}+\mathrm{Ni}$ & $\mathrm{N}-\ldots=\mathrm{cut}=\mathrm{Cys}-\ldots-\mathrm{C}$ \\
\hline
\end{tabular}

Selected peptidases for cleaving a peptide after or before one or more specific amino acids (Stage 1 or Stage 2) (Alternative target, usually less probable, is in parentheses.)

\begin{tabular}{|c|c|c|c|c|c|}
\hline & & & & & \\
\hline Peptidase & Cleavage point & Target X (or Z) & Peptidase & Cleavage point & Target $X$ \\
\hline $\mathrm{ArgC}$ proteinase & $\mathrm{N}-\ldots-\mathrm{X}=\mathrm{cut}=\ldots-\mathrm{C}$ & $X=\operatorname{Arg}$ & $\mathrm{ArgC}$ endopeptidase & $\mathrm{N}-\ldots-\mathrm{X}=\mathrm{cut}=\ldots-\mathrm{C}$ & $\mathrm{X}=\operatorname{Arg}($ Lys $)$ \\
\hline AspN endopeptidase & $\mathrm{N}-\ldots=\mathrm{cut}=\mathrm{X}-\ldots-\mathrm{C}$ & $\mathrm{X}=\mathrm{Asp}(\mathrm{Glu})$ & LysC endopeptidase & $\mathrm{N}-\ldots-\mathrm{X}=\mathrm{cut}=\ldots-\mathrm{C}$ & $\mathrm{X}=$ Lys (Asn) \\
\hline Trypsin & $\mathrm{N}-\ldots \mathrm{X}=\mathrm{cut}=\mathrm{Z}-\ldots-\mathrm{C}$ & $X=\operatorname{Arg}$ or Lys $\quad Z \neq$ Pro & LysC lysyl endopeptidase & $\mathrm{N}-\ldots-\mathrm{X}=$ cut $=\ldots-\mathrm{C}$ & $\mathrm{X}=$ Lys \\
\hline $\begin{array}{l}\text { LysN peptidyl } \\
\text { metalloendopeptidase }\end{array}$ & $\mathrm{N}-\ldots=\mathrm{cut}=\mathrm{X}-\ldots-\mathrm{C}$ & $\mathrm{X}=$ Lys & Neutrophil elastase & $\mathrm{N}-\ldots-\mathrm{X}=\mathrm{cut}=\ldots-\mathrm{C}$ & $\mathrm{X}=$ Val or Ala \\
\hline Glutamyl endopeptidase & $\mathrm{N}-\ldots-\mathrm{X}=\mathrm{cut}=\ldots-\mathrm{C}$ & $\mathrm{X}=\mathrm{Glu}$ & & & \\
\hline
\end{tabular}

\section{A-7 Additional notes and references}

1) Order of fragment entry into DNP. A fragment can enter DNP amino-end first or carboxy-end first. However the order is not important as the information sought is the number of residues, not their identity or sequence.

2) Order of entry of peptide into UNF. The assembly algorithm described in Section 2 implicitly assumes that entry of a peptide into UNP in each of the cells is all of them either N-terminal first or C-terminal first. This is a reasonable assumption because of the charged Xheader. However, there is a non-zero probability that the peptide may enter wrong end first, so some of the fragment length lists obtained will be in the reverse order. The assembly algorithm needs to be modified to take this into account.

3) Applied voltage and current levels. Blockades are of ionic current flow through the pore due to $\mathrm{K}+$ and $\mathrm{Cl}$ - ions in the electrolyte; with $\mathrm{V}=\sim 100 \mathrm{mV}$ this current is $\sim 100 \mathrm{pA}\left(\approx \mathrm{G}_{\text {pore }} \mathrm{V}\right.$, where $\mathrm{G}_{\text {pore }}$ is the conductance of the pore, typically $1 \mathrm{nS}$ for a pore $\sim 10 \mathrm{~nm}$ long), usually adequate for measuring blockades [6]. With longer pores blockade levels may be lower. In the presence of noise there is a tradeoff 
between detectable pulse amplitude changes and translocation speed. While a higher voltage results in a higher blockade current and higher signal-to-noise ratios (SNR), it also causes a fragment or residue with high negative charge to translocate through DNP at a rate that exceeds $1 / \mathrm{T}_{\text {detector }}$, and one with high positive charge to translocate too slowly, resulting in misses or 'loss' to diffusion respectively. These extremes have been estimated in Section A-3 above. (The upper limit to the applied voltage is set by the breakdown field for the electrolyte, typically $\sim 70 \mathrm{MV} / \mathrm{m}$.)

4) Entropy barriers. It is assumed that the entropy barrier [6] faced by a fragment during its entry into DNP (Method 1) or MNP (Method 2) is negligible, in part because short peptides have been considered. Long peptides may form secondary structures and also ball up, impeding entry into a pore. In this case, the barrier may not be negligible; it can be taken into account by increasing the minimum cleaving intervals required of the enzymes. The taper in trans $1 /$ cis 2 and trans $2 / c i s 3$ (Figures 1 and 2) also helps lower the entropy barrier. Based on the computational results discussed above, the two methods presented here appear well suited to sequencing of peptides with 12-16 residues. (Compare with the optimum peptide length of $\sim 20$ in an efficient mass spectrometer [3].)

5) Independence of cells. Each cell targets a different amino acid and operates independent of the other cells. This means that the cell can be independently optimized for enzyme reaction rates, applied voltage, $\mathrm{pH}$ value, etc.

6) Sticky fragments/residues. The problem of fragments or residues sticking to pore or compartment walls may be resolved through the use of non-stick additives [39] or wall coatings [40].

7) Sequencing with the potential reversed. A peptide can be sequenced with the applied potential reversed, which speeds up fragments with positive charge and slows down those with negative charge; neutral fragments are not affected. (If the pore is ion-sensitive, one with the appropriate sense may be used.) Merging the two sets of data can lead to improvements in detection and correction of errors, but this is only for charged fragments. The error can be minimized over all fragments, charged or neutral, by experimentally varying the $\mathrm{pH}$ and finding the $\mathrm{pH}$ value that yields the best results.

8) Hafnium oxide pores. Recent studies using high bandwidth $(\sim 4 \mathrm{MHz})$ detectors have shown that a $\mathrm{HfO}_{2}$ membrane $<10$ nm thick can slow down translocating DNA molecules [41]. (The slowdown is believed to be due to interactions of the DNA with the walls of the pore.) At the present time, however, fabrication seems to require an inordinate amount of time.

For other implementation-related issues affecting tandem cells see discussions in [11,12].

\section{References}

[34] D. L. Nelson and M. M. Cox, Lehninger's Principles of Biochemistry, 4th Edition, W. H. Freeman and Company, New York, 2005.

[35] M. W. Germann, T. Turner, and S. A. Allison, "Translational diffusion constants of the amino acids: measurement by NMR and their use in modeling the transport of peptides," J. Phys. Chem. A, 2007, 111, 1452-1455.

[36] R. J. Simpson, Proteins and Proteomics: A Laboratory Manual, Cold Spring Harbor Laboratory Press, Cold Spring Harbor, NY, 2008.

[37] J. H. Werner, H. Cai, R. A. Keller, P. M. Goodwin, “Exonuclease I hydrolyzes DNA with a distribution of rates,” Biophys. J., 2005, 88, 14031412.

[38] A. J. Barrett, N. D. Rawlings, and J. F. Woessner, (eds.) Handbook of Proteolytic Enzymes, Academic Press, London, 1998.

[39] E. C. Yusko, J. M. Johnson, S. Majd, P. Prangkio, R. C. Rollings, J. Li, J. Yang, and M. Mayer, "Controlling protein translocation through nanopores with bio-inspired fluid walls", Nature Nanotech., 2011, 6, 253-260.

[40] G. F. Schneider, S. W. Kowalczyk, V. E. Calado, G. Pandraud, H. W. Zandbergen, L. M. K. Vandersypen, and C. Dekker, "DNA translocation through graphene nanopores", Nano Lett., 2010, 10, 3163-3167.

[41] J. Larkin, R. Henley, D. C. Bell, T. Cohen-Karni, J. K. Rosenstein, and M. Wanunu, "Slow DNA transport through nanopores in hafnium oxide membranes," ACS Nano, 2013, 7, 10121-10128. 